Study Abroad/Reflection Article

ISSN: 2162-3104 Print/ ISSN: 2166-3750 Online

Volume 5, Issue 4 (2015), pp. 541-544

(C) Journal of International Students

http://jistudents.org/

\title{
The Not-So-Easy Road of Overseas Study: Life like an Outsider
}

\author{
Yolanda Palmer, $\mathrm{PhD}$ \\ University of Saskatchewan (Canada)
}

\begin{abstract}
Contemplating my graduate student experience overseas, I constantly viewed myself as an isolate, one who did not belong in the new community of practice. I encountered numerous lingua-cultural, academic and social challenges which led to my lack of community and belonging. This paper is a reflection of my experiences as an international graduate student in a Canadian university. Through this reflection, I explore some of my most potent experiences and how these influenced me as I sojourned through the not-so-easy road of study overseas. This paper also describes the processes I used that enabled me to successfully maneuver and negotiate my journey on the not-so easy-road of studying in a post-secondary institution overseas.
\end{abstract}

Keywords: International students, community of practice, sense of belonging and community

As I ruminate on my international student experience the lyrics of Buju Banton's song "Not an easy road" come readily to my mind: It is not an easy road..., but who feels it knows... Lord help me sustain these blows... Obstacles in your way to overcome first... (1995) became my daily chant as I faced each new day in the university. These words constantly reminded me of my journey as an international graduate student setting out my quest to study abroad. The road is never easy but I had to learn the ways of the new community and be successful in my academic pursuits.

The social nature of learning (Bourdieu, 1986; Vygotsky, 1988) predicates that students should experience a sense of community within learning environments. McMillan and Chavis (1986) defined sense of community as a "feeling that members have of belonging, a feeling that members matter to one another and to the group, and a shared faith that members' needs will be met through their commitment to be together" (p. 9). Lave and Wenger (1991) stressed the importance of belonging and participating in the community of practice. For Lave and Wenger, belonging and fitting in enhances the learning opportunities and successes of individuals. Also important in achieving a sense of community is a sense of place-being comfortable in the physical environment—in which they study.

\section{My First Day as an International Student}

As I engaged my program of study as an international student, in 2011, I felt like an isolate in the community of practice-groups of people who share a common concern or passion for something they do and learn how to do it better as they interact regularly—and lacking a sense of belonging. I immediately thought, "I am a long way from home." As a Jamaican scholar, I was aware of the imminent journey upon which I was embarking. Entering the Canadian postsecondary institution from a rich cultural, linguistic and academic background, I was highly 
aware of the differences between "here" and "there." My approach to studies and daily life contrasted starkly to the way things were done at the university.

Clearly etched in my mind are the conflicting feelings I experienced on my first day on the not-so-easy road of international studentship. I approached the class with masked feelings of excitement and nervousness. I had the uneasy feeling of being in a foreign institution and found myself wondering: What was I thinking? I began questioning my position in the new academy, What am I doing here? Do I really belong here? During the process of the customary introductions it became clear to me that I was the "other" amidst the group. My Jamaican accent was pronounced and obviously different. To make matters worse, I did not understand nor could I react to the banters of other members of the class. As I attended university functions and even got involved in church and community activities, I struggled with my position among the groups. I constantly reflected on my life back home and the varied academic, social and cultural differences within the new communities of practice.

\section{As an Outsider: My Attempts at Belonging}

Our cultural identities differ one from the other and determine the way we respond to stimuli around us; it fuels how we perform verbally and nonverbally (Bonvillian, 2000). Being a Jamaican female largely dictates how I act in certain situations, how I learn and how I appropriate myself within the learning institution. My ideas, ways of thinking and doing things never seemed to align with those of the new environment. These experiences and feelings reminded me of the work of bell hooks (1988), who in her book Talking back, writes about the isolation and bewilderment she felt as she studied in a predominantly white college. A particular area of her story that resonated with me was the fact that as a minority student she felt she did not fit into the university and classes she attended, but was determined not to be a failure. I too understood that I was different and possessed diverse skills and was determined to do what it took to be successful.

My background as a teacher and scholar predisposed me to certain deep-rooted notions of schooling and the expectations of being a student. I had mastered my roles of being both a teacher and a student in Jamaica. So when I decided to engage in studies as an international student, I thought I was ready for the journey; after all, I had significant experiences as a student. After my experience as an international student, I realized that the two experiences significantly differed, and the cultural ethos of the university and its surrounding community was not similar to that with which I had become accustomed in Jamaica. Further, this was exasperated by my lack of the cultural, social and sometimes economic capital which would have increased my chances of gaining a sense of belonging within my new community of practice.

In my home country, Jamaica, I learned to show respect to elders and people in authority. Respect in this regard meant that I learned to address people the "proper way" by adorning them with their corresponding accolades when greeting and or communicating with them. The trend of addressing professors at my new institution by their first names, rather than the customary acknowledgement of "doctor" or "professor" was strange to me. Furthermore, the academic culture, rhetoric and protocols used and expected of me were foreign to me. Words, terminologies and protocols in my previous studentship with which I had become accustomed were sometimes unrecognized in the new academy. Added to this, the language that permeated the academic and general local milieu was unfamiliar to me and other foreign students. Academic culture in my previous studentship, in regard to written presentations, was marked by strict rules and guidelines regarding how papers were to be written. Owing to the perceived

September/October $2015 \quad$ http:/jistudents.org $\quad$ Volume $5 \bullet$ Issue 4


neutrality of academic writing the use of the first person in writing tasks was often highlighted and identified as inappropriate. Entering into this new institution the culture of writing was characteristically different. Evident to me, in the host academy, is the use of critical thought and a more relaxed atmosphere in the production of assigned coursework. I was accustomed to writing to structured questions that outlined exactly, on point, what I needed to write and what my professor hoped to read. I soon learned that this was not the culture of the particular department of which I was a part. Free thought and critical thinking were encouraged and students were allowed to write about their own interests.

As I reflect, I realized that not only was I faced with a lack of belonging and community but also suffered from a lack of sense of place. I am from Jamaica, which is physically and geographically located within the tropical zone. Hence, as a people we experience higher temperatures year-round. I have never before experienced such bone-chilling cold, nor was I accustomed to seeing and feeling the white fluffy snow that forms part of the Canadian physical landscape for prolonged periods. As I permeated the path to scholarship, I struggled with the shifting temperatures and especially with the low temperatures during the winter period.

\section{Negotiating the New Academic Culture}

As I progressed on the journey from being an international graduate student to becoming a scholar, I realized that I entered the environment from a country with a rich colonial history steeped in hegemony that had Anglicized my perspectives. These viewpoints fostered expectations and assumptions about my culture and cultures globally. I accepted and realized that I was in a new community of practice and I did not particularly feel that I fit in. As a learner, I understood that learning is transformational and that if I were to be transformed I had to take responsibility for my own learning and journey in the university and anticipate my role as a scholar and educator to assist others in finding their ways. Essentially, I had to engage the community in which I found myself and through situated learning move inward from being a peripheral learner into the community of practice through my earned capital. This recognition and the motivation I had to accomplish my goal of successful completion of my graduate studies helped me to begin to critically reflect on my role as a student and individual. Who I am and what I hoped to accomplish were "put through the wringer," and from this process of contemplation I was able to look past the issues I perceived and encountered.

Kim (2001) argued that for international students to become insiders they must participate in academic, cultural and social activities within the new environment. Participation in these activities, according to Kim, provides these individuals the requisite knowledge, skills, sensitivities and behaviors that will allow them to function as members of the group. For me, acquiring these skills was difficult because I had entered the community of practice already acculturated in my Jamaican culture and ethnic behaviors. However, through a multilayered practice of observing, listening, speaking, reading and writing I became engaged in self-praxis. Praxis involves "critical reflection-and action upon-a situation of some degree shared by persons with common interests and common needs" (Greene, 1978, p. 100). Essentially, I needed to take ownership of my life and its trajectory so I became an active participant in my learning and through this I began to strengthen and interweave strands of language, literacy and content learning (Zwiers, 2008).

As I reflected on my experiences, I came to the understanding that my strength was evinced through my becoming more participatory in academic discussions, as I learned increasingly challenging concepts and developed the language abilities to act accordingly. I 
realized that which caused me to "bounce back" came through my religious beliefs. When faced with challenges I reflected on and channeled my energies through these beliefs. Realizing and accepting my situation in the social world of the academy, I was able to gain access to sources of understanding through a growing involvement within the social practice of the classroom community. Through peripheral participation and practice, I have been transformed from a state of powerlessness and dependence to one of empowerment, self-reliance and independence.

\section{Continuing on the Journey: Making the Trek Easier}

After more than two years as a full-time graduate student in Canada, I have come to recognize and appreciate my position. I often felt like an invader in the spaces and places of local students. As a newcomer, I struggled with being in a different social, lingua-cultural and academic environment. I felt the pangs of nostalgia while glaring into wild isolation. I battled the harsh weather conditions and contemplated and overcame dire economic odds.

Yet, as I grew to appreciate the ethos of the institution my conversations and interactions with local and international students as well as faculty and other staff within the University continually left me with mixed feelings. I was torn between "there" and "here": my country of origin, Jamaica, and Canada, my country of temporary settlement. I wandered between the two worlds because I knew I had to return to my homeland and regain my life after completion of my studies. Yet, I had to live and fit into the Canadian culture and lifestyle. I was always conscious of my outsider position; this kept me grounded and focused on being successful. It was not an easy road but through participation, praxis and practice it got easier as the days progressed.

\section{REFERENCES}

Banton, Buju. "Its not an easy road.” Til Shiloh, 1995. MP3.

Bonvillain, N. (2000). Language culture and communication: the meaning of messages. Englewood Cliffs, NJ: Prentice Hall.

Bourdieu, P. (1986). The forms of capital. Bourdieu, P. (1986) In J. Richardson (Ed.), Handbook of Theory and Research for the Sociology of Education (pp. 241-258). New York, NY: Greenwood.

Greene, M. (1978). Landscapes of leaning. New York, NY: Teachers College Press.

hooks, b. (1988). Talking back. Toronto, Ontario: Between the Lines.

Kim, Y. Y. (2001). Becoming intercultural: An integrative theory of communication and crosscultural adaptation. Thousand Oaks: Sage Publications.

McMillan, D.W. \& Chavis, D.M. (1986). Sense of community: A definition and theory. American Journal of Community Psychology, 14(1), 6-23.

Lave, J. \& Wenger, E. (1991). Situated learning: Legitimate peripheral participation. New York, NY: Cambridge University Press.

Vygotsky, L. (1988). Thought and language. Alex Kozulin (Trans.). Cambridge, MA: The MIT Press.

Zwiers, J. (2008). Building academic language: Essential practices for content classrooms. San Francisco, CA: Jossey-Bass.

\section{AUTHOR}

YOLANDA PALMER is a sessional lecturer in the college of education at the University of Saskatchewan, Canada. Her areas of interest and research include transcultural academic literacies, multilingual and multicultural education, ecology of languages, pedagogies of language, triple learning and lingua-cultural identities. Email: yolanda.palmer@usask.ca 